\title{
Differences of viral panel positive versus negative by real-time PCR in COPD exacerbated patients
}

\author{
Burcu YORMAZ ${ }^{1}$ \\ Duygu FINDIK ${ }^{2}$ \\ Mecit SÜERDEM ${ }^{1}$
}

${ }^{1}$ Department of Chest Diseases, Faculty of Medicine, Selcuk University, Konya, Turkey

${ }^{1}$ Selçuk Üniversitesi Tıp Fakültesi, Göğüs Hastalıkları Anabilim Dalı, Konya, Türkiye

${ }^{2}$ Department of Medical Microbiology, Faculty of Medicine, Selcuk University, Konya, Turkey

${ }^{2}$ Selçuk Üniversitesi Tıp Fakültesi, Mikrobiyoloji Anabilim Dalı, Konya, Türkiye
Cite this arcticle as: Yormaz B, Süerdem $M$, Fındık $D$. Differences of viral panel positive versus negative by realtime PCR in COPD exacerbated patients. Tuberk Toraks 2019;67(2):124-30

\section{Yazışma Adresi (Address for Correspondence)}

\section{Dr. Burcu YORMAZ}

Selçuk Üniversitesi Tıp Fakültesi,

Göğüs Hastalıkları Anabilim Dalı, KONYA - TÜRKIYE

e-mail: burcyormaz@gmail.com

OCopyright 2019 by Tuberculosis and Thorax. Available on-line at www.tuberktoraks.org.com

\section{SUMMARY}

Differences of viral panel positive versus negative by real-time PCR in COPD exacerbated patients

Introduction: Exacerbations of chronic obstructive pulmonary disease (COPD) are often caused by respiratory tract infections. The aim of this study was to investigate the clinical, laboratory and computed tomography features of patients with hospitalized COPD exacerbations in which respiratory viruses were detected using a real-time polymerase chain reaction $(P C R)$ technique.

Materials and Methods: This retrospectively planned study included patients hospitalized in the chest diseases clinic due to exacerbation of COPD between November 2018-February 2019. The study included patients who had virus-specific real-time $P C R$, and computed tomography scans of the chest.

Results: A total of 110 patients were included in the study. Respiratory viruses were identified in the nasopharyngeal swabs of 50 patients $(45.5 \%)$ using the real-time PCR method, with rhinovirus $(25 \%)$, influenza $A(13.1 \%)$ and coronavirus $(11.8 \%)$ being the most commonly isolated agents. The mean age of the patients was $68.28 \pm 9.59$ years in the virus-positive group and $68.20 \pm 8.27$ years in the virus-negative group $(p=0.963)$. Gender distribution, rate of smokers, exposure to biofuels, blood leukocyte count, neutrophil percentage, C-reactive protein (CRP) level, FEV $/ F V C$ ratio did not significantly differ between the two groups ( $p>0.05)$. Procalcitonin $(P C T)$ and $F E V_{1}$ values were significantly lower ( $p=0.001$ and $p=0.028$, respectively) and the number of exacerbations was significantly higher in the virus-positive group ( $p=0.001$ ). The length of hospital stay was longer in the virus-positive group than in the virus-negative group $(p=0.012)$. Among the findings of computed tomography (CT) of the chest, bronchial wall thickening, cystic 
bronchiectasis, and emphysema did not differ significantly ( $p>0.05)$. The rate of infiltrative lesions (tree-in-bud opacity, ground-glass opacity, atypical pneumonia) was significantly higher in the virus-positive group $(p=0.020)$.

Conclusion: Viral respiratory tract infections should be considered in hospitalized patients with an exacerbation of COPD who have a history of frequent exacerbations, normal PCT value, and the absence of consolidation in CT scan of the chest. The use of broadspectrum antibiotic therapy should be avoided in patients with these features.

Key words: Chronic obstructive pulmonary disease; procalcitonin; viral respiratory panel

\section{ÖZET}

\section{KOAH alevlenmeli hastalarda gerçek zamanlı PCR tekniğiyle viral panel pozitif olanların negatif olanlardan farklılı̆̆ı}

Giriş: Kronik obstrüktif akciğer hastalığı (KOAH)'nın alevlenmesi genellikle solunum yolu infeksiyonlarından kaynaklanır. Bu çalışmanın amacı, gerçek zamanlı polimeraz zincir reaksiyonu (PCR) tekniği kullanılarak solunum yolu virüslerinin tespit edildiği hastane yatısıı olan KOAH alevlenmeli hastaların klinik, laboratuvar ve bilgisayarlı tomografi özelliklerini araştırmaktı.

Materyal ve Metod: Retrospektif olarak planlanan bu çalışmaya, Kasım 2018-Şubat 2019 tarihleri arasında KOAH alevlenmesi nedeniyle gögü̈s hastalıkları kliniğinde yatan hastalar alındı. Çalışma, virüse özgü gerçek zamanlı PCR tekniği ile viral panel bakılmış ve akciğer tomografisi olan hastaları içermektedir.

Bulgular: Toplam 110 hasta çalışmaya dahil edildi. Elli hastanın (\%45.5) nazofarengeal sürüntülerinde solunum virüsleri, gerçek zamanlı PCR yöntemi kullanılarak tanımlandı, rinovirüs (\%25), influenza A (\%13.1) ve coronavirüs (\%11.8) en sık izole edilen ajanlardı. Hastaların yaş ortalaması virüs pozitif grupta $68.28 \pm 9.59$ ve virüs negatif grupta $68.20 \pm 8.27(p=0.963)$ idi. Cinsiyet dağılımı, sigara içenlerin oranı, biyoyakıt maruziyeti, kan lökosit sayısı, nötrofil yüzdesi, C-reaktif protein (CRP) düzeyi, FEV 1 /FVC oranı bakımından iki grup arasında anlamlı fark görülmedi ( $p>0.05)$. Virüs pozitif grupta, Prokalsitonin (PCT) ve FEV 1 değerleri anlamlı derecede düşüktü (sırasılla $p=0.001$ ve $p=0.028$ ) ve alevlenme sayısı anlamlı olarak daha yüksekti $(p=0.001)$. Hastanede kalış süresi virüs pozitif grupta virüs negatif gruptan daha uzundu $(p=0.012)$. Bilgisayarlı tomografi $(B T)$, bronş duvarı kalınlaşması, kistik bronşektazi ve amfizem bulguları arasında anlamlı fark bulunmadı ( $p>0.05$ ). Virüs pozitif grupta infiltratif lezyonların oranı (tomurcuklanmış ağaç opasitesi, buzlu cam opasitesi, atipik pnömoni) anlamlı olarak yüksekti ( $p=0.020)$.

Sonuç: Sık alevlenme öyküsü mevcut, normal PCT değeri olan ve göğ̈̈s tomografisinde konsolidasyon bulunmayan KOAH alevlenme nedeniyle hastane yatışı olan hastalarda viral solunum yolu infeksiyonları düşünülmelidir. Bu özelliklere sahip hastalarda geniş spektrumlu antibiyotik tedavisi kullanmaktan kaçınılmalıdır.

Anahtar kelimeler: Kronik obstrüktif akciğer hastalı̆̆ı; prokalsitonin; viral respiratuvar panel

\section{INTRODUCTION}

Chronic obstructive pulmonary disease (COPD) is a preventable and treatable disease that is characterized by airflow restriction and respiratory symptoms resulting from severe exposure to harmful particles or gases (1). COPD is associated with episodes of acute deterioration that are termed as "exacerbations", and which are characterized by worsening symptoms (worsening dyspnea, cough, increased volume of sputum and/or changes in color, increased wheezing, chest discomfort) from the usual stable state $(1,2)$. COPD exacerbationis a global problem due to accelerated disease progression, a decline in quality of life, increased risk of mortality and increased healthcare costs $(1,3,4)$.

COPD exacerbations have various infectious and non-infectious causes. Approximately $70 \%$ of exacerbations in COPD are caused by respiratory tract infections brought on by bacteria, viruses and atypical bacteria $(5,6)$. Respiratory viruses are considered to be among the most important triggers of exacerba- tions. Between $15 \%$ and up to $64 \%$ of COPD exacerbations have been found to be associated with symptomatic colds precipitated by viruses $(5,7,8)$. The prevalence of respiratory viruses in COPD patients can vary widely depending on geography and local epidemiologic trends (9).

Virus-induced COPD exacerbations occur with much greater frequency during the winter months when respiratory viral infections are prevalent in the community (10). Co-infection by bacteria and viruses has been described in up to $25 \%$ of hospitalized patients, suggesting a certain susceptibility to bacterial infection after a viral process (11). The management of exacerbations of COPD depends on the severity and the cause of infection (bacterial or viral). It would be a logical approach for countries to update their epidemiological data on a regular basis as a guide for empirical antibiotherapy in COPD exacerbations. In this study, we aimed to determine the frequency of viral infections and to evaluate the clinical, radiological and laboratory characteristics of these hospitalized COPD patients due to exacerbation. 


\section{MATERIALS and METHODS}

\section{Subject Selection}

The study was planned retrospectively and COPD patients who were hospitalized due to exacerbation between November 2018-February 2019 were included in the study. We selected patient files containing nasopharyngeal swabs for the panel of respiratory viruses, CRP, PCT, and scans of the chest for the study. Patients with comorbid diseases such as diabetes mellitus, hypertension, thyroid disease and coronary artery disease that would not affect the laboratory markers of infections were included in the study. Patients with one or more conditions that may cause dyspnea, such as asthma, pulmonary embolism, thromboembolism, pneumothorax, congestive heart failure or lung cancer were excluded from the study, even if they had been hospitalized due to COPD exacerbation. Furthermore, patients with an active fungal infection that may affect PCT levels and those with systemic infections other than a lung infection were also excluded. Patients with an appearance of pneumonic consolidation on a chest X-Ray were also excluded. The study was approved by the ethical committee of the Selcuk University Medical School.

\section{Real-Time PCR}

The nasopharyngeal swabs are taken before antibiotic treatment and stored at -20 degrees until the time of analysis. In the multiplex PCR analysis, which was performed in eight tubes, the following agents were investigated: influenza A virus, influenza B virus, influenza $C$ virus, influenza A (H1N1)-swl virus, human parainfluenza viruses $1-4$, human coronaviruses NL63, 229E, OC43 and HKU1, human metapneumoviruses $\mathrm{A} / \mathrm{B}$, human rhinovirus, human respiratory syncytial viruses $A / B$, human adenovirus, enterovirus, human parechovirus, human bocavirus, Pneumocystis jirovecii, Mycoplasma pneumoniae, Chlamydophila pneumoniae, Streptococcus pneumoniae, Haemophilusinfluenzae type B, Staphylococcus aureus, Moraxella catarrhalis, Bordetella spp. (excluding Bordetella parapertussis), Klebsiella pneumoniae, Legionella pneumophilal longbeachae, Salmonella spp. and Haemophilus influenzae. Due to the specificity of the test, the test results were include viruses together with bacteria. Therefore, only isolated virus-identified panels were evaluated as viral panel-positive.

\section{Pulmonary Function Test}

All spirometric examinations were carried out using a single pulmonary function testing system (Viasys Master Scope, Germany) by a certified and experienced technician, in accordance with the American Thoracic Society/European Respiratory Society (ATS/ ERS) criteria. According to the rules of our clinic, inpatient spirometry is performed when respiratory distress is reduced.

\section{CT Examination}

The low dose CT scans of the chest without contrast enhancement are performed in hospitalized patients due to exacerbation of COPD for phenotype assessment and lung cancer screening according to our clinical rules. All CT examinations were performed using a 128 multidetector CT scanner (Siemens Healthcare, Erlangen, Germany) at a radiation exposure of $100 \mathrm{~mA}$. The thoracic CT scans were interpreted by dividing them into five groups, being: bronchial wall thickening according to the parenchyma window, bronchiectasis, emphysema, infiltrative lesion and normal.

\section{Statistical Analysis}

The first hematological, CRP and PCT values were taken into account in the statistical calculation. A Shapiro-Wilk test was used for each parameter to test for the normal distribution of data. An independent samples t-test was used to compare two independent groups with normal distribution, a Mann-Whitney U-test was used to compare two independent groups without normal distribution, and a Chi-square test with a Yates's continuity correction and Fisher's exact test were used for the analysis of categorical variables. All analyses were evaluated with an alpha level of 0.05 (95\% confidence interval).

\section{RESULTS}

Included in the study were 110 patients. A respiratory virus was identified in the viral panel in 50 patients $(45.5 \%)$, and the patients were divided into two groups as viral panel-positive and viral panel-negative. The panels of bacteria identified together with respiratory viruses were considered as viral panel-negative. Therefore, only isolated virus-identified panels were evaluated. A comparison of the variables between the two groups is presented in Table 1. The mean age was $68.28 \pm 9.59$ years in the viral pan- 
Table 1. Between-group comparison of variables

\begin{tabular}{|c|c|c|c|}
\hline & VP (50) & VN (60) & $\mathbf{p}$ \\
\hline Age & $68.28 \pm 9.59$ & $68.20 \pm 8.27$ & 0.963 \\
\hline \multicolumn{4}{|l|}{ Gender, n (\%) } \\
\hline Female & $10(20)$ & $20(33.3)$ & 0.117 \\
\hline Male & $40(80)$ & $40(66.7)$ & \\
\hline Smoking (package/year) & $33.12 \pm 28.92$ & $32.33 \pm 32.88$ & 0.651 \\
\hline Biofuel (years) & $40.42 \pm 22.00$ & $43.73 \pm 16.42$ & 0.456 \\
\hline $\mathrm{FEV}_{1} / \mathrm{FVC}$ & $51.94 \pm 10.90$ & $57.62 \pm 9.85$ & 0.474 \\
\hline $\mathrm{FEV}_{1}(\%)$ & $46.96 \pm 21.12$ & $56.33 \pm 16.42$ & 0.028 \\
\hline Number of exacerbations (Last one year) & $3.14 \pm 1.21$ & $2.17 \pm 0.98$ & 0.001 \\
\hline Length of hospital stay & $10.12 \pm 4.60$ & $8.53 \pm 3.95$ & 0.012 \\
\hline WBC (K/uL) & $12.68 \pm 5.97$ & $12.00 \pm 4.58$ & 0.831 \\
\hline Neutrophil (\%) & $79.27 \pm 8.82$ & $76.97 \pm 10.92$ & 0.232 \\
\hline $\mathrm{CRP}(\mathrm{mg} / \mathrm{dL})$ & $5.36 \pm 4.76$ & $5.90 \pm 5.89$ & 0.918 \\
\hline Procalcitonin (ug/L) & $0.12 \pm 0.10$ & $0.051 \pm 0.020$ & 0.001 \\
\hline Blood eosinophil (K/uL) & $0.031 \pm 0.03$ & $0.15 \pm 0.16$ & 0.001 \\
\hline
\end{tabular}

el-positive group and $68.20 \pm 8.27$ years in the viral panel-negative group, with no significant difference being identified between the two groups $(p=0.963)$. There was no significant difference between the two groups in terms of gender distribution, rate of smokers (pack/year), exposure to biofuels (years), blood leukocyte count $(\mathrm{K} / \mathrm{uL})$, neutrophil percentage, CRP level $(\mathrm{mg} / \mathrm{dL})$ or $\mathrm{FEV}_{1} / \mathrm{FVC}$ ratio $(\mathrm{p}>0.05)$. The mean blood eosinophil count was significantly higher in the viral panel-negative group than in the other group $(p=$ $0.001)$. PCT and $\mathrm{FEV}_{1}(\%)$ values were significantly lower $(p=0.001$ and $p=0.028$, respectively) and the number of exacerbations was significantly higher in the virus-positive group $(p=0.001)$. The length of hospital stay was longer in the virus-positive group than in the virus-negative group $(p=0.012)$.

A total of 76 viral pathogens were identified in the viral panel-positive group, with the most frequently isolated pathogens being rhinovirus, influenza $A$ and coronavirus (Table 2). Rhinovirus was positive in 19 patients and constituted $25 \%$ of all agents. Among the findings of the computed chest tomography, no significant difference was found between bronchial wall thickening, cystic bronchiectasis and emphysema ( $p>$ 0.05). The rate of infiltrative lesion (tree-in-bud opacity, atypical pneumonia) was significantly higher in the viral panel-positive group $(p=0.020)$ (Table 3$)$.
Table 2. Number and percentage of the causative agents isolated from the virus-positive group

\begin{tabular}{|lc|}
\hline Agents & n (\%) \\
\hline Rhinovirus & $19(25)$ \\
Influenza A & $10(13.1)$ \\
Coronavirus & $9(11.8)$ \\
Influenza B & $8(10.5)$ \\
RSVA & $7(9.2)$ \\
RSVB & $7(9.2)$ \\
H1N1 & $4(5.2)$ \\
Human metapneumovirus A & $3(3.9)$ \\
Human metapneumovirus B & $3(3.9)$ \\
Parainfluenza B & $2(2.6)$ \\
Enterovirus & $2(2.6)$ \\
Adenovirus & $1(1.3)$ \\
\hline
\end{tabular}

\section{DISCUSSION}

The main findings of this study were that respiratory viruses were frequently detected during exacerbations of COPD patients admitted to hospital. Rhinovirus, influenza virus and coronavirus were higher in viral panel-positive group. PCT and $\mathrm{FEV}_{1}$ were lower and the number of exacerbations over the past one year were higher in viral panel-positive group. 
Differences of viral panel positive versus negative by real-time PCR in COPD exacerbated patients

\begin{tabular}{|c|c|c|c|}
\hline & VP (50) & VN (60) & $\mathbf{p}$ \\
\hline Bronchial wall thickening, n (\%) & $21(42)$ & $29(58)$ & 1.000 \\
\hline Bronchiectasis, n (\%) & $10(20)$ & $40(80)$ & 0.850 \\
\hline Emphysema, n (\%) & $31(62)$ & $28(46.7)$ & 0.157 \\
\hline Infiltrative lesion, n (\%) & $18(36)$ & $9(15)$ & 0.020 \\
\hline Normal, n (\%) & $5(10)$ & $11(18.3)$ & 0.336 \\
\hline
\end{tabular}

The prevalence of respiratory viruses in COPD exacerbation has been underestimated. Older studies using cultures or serological methods reported rates of isolation for respiratory viruses that range from $10-30 \%(12,13)$. The weighted mean prevalence value of respiratory viral infections detected by PCR and/or Reverse Transcriptase PCR in COPD exacerbations in a systematic review reported $34.1 \%$ (14). The lowest prevalence rate for respiratory viral infections in literature has been reported in the United States (15). In this study, respiratory viruses were identified from nasal swabs using the PCR method in $25 \%$ of patients who presented to the emergency room with COPD exacerbation. Rohde et al. detected respiratory viruses in the sputum and nasal lavage samples of $56 \%$ (48/85) of patients with COPD that were hospitalized with exacerbation (16). Respiratory viruses were detected by a microarray technique in $53.5 \%(107 / 200)$ of hospitalized patients with COPD exacerbation in Greece (17).

Rhinovirus, RSV and influenza are the most common viral agents associated with COPD exacerbation and rhinovirus was the most common agent identified in the present study $(5,8)$. Studies of COPD in Western counties have identified rhinovirus as the most common infectious agent $(7,16,18)$. Rhinovirus is responsible for the common cold, and respiratory viral infections have been identified as important triggers of COPD exacerbations. In a study of 83 patients conducted by Seemungal et al. in the United Kingdom, rhinovirus was detected in $58.2 \%$ of the patients (7). Rohde et al. detected rhinovirus in 36\% and influenza in $25 \%$ of patients hospitalized with exacerbation of COPD (16). The rate of rhinovirus was $20.1 \%$ and the rate of influenza was $8.2 \%$ in a US study that involved patients hospitalized with exacerbation of COPD (18). In a study by Dimopoulos et al., RSV (40.5\%), influenza virus $(11 \%)$ and rhinovirus $(8 \%)$ were the most commonly identified virus- es (17). In an Asian study, influenza A (7.3\%) was the most commonly detected viral agent (9). In their study, a prevalence rate of $4.6 \%$ was reported for coronavirus and $3.1 \%$ for rhinovirus. The differences between studies may be attributed to the different rates of influenza vaccination.

Exacerbations associated with viruses tend to have greater effects on the airway and greater systemic inflammatory effects than non-viral infections (14). Viral exacerbations appear to be more severe, as reflected in the length of hospitalization, the decrease in $\mathrm{FEV}_{1}, \mathrm{FEV}_{1} \%, \mathrm{FEV}_{1} / \mathrm{FVC} \%$ and diffusion capacity, and with a trend towards greater hypoxemia (14). Dai et al. showed that the length of hospital stay associated with exacerbations of COPD was higher in the coinfection group from which viruses and bacterial agents are isolated simultaneously than in exacerbations caused by bacterial agents and non-infectious exacerbations (19). Restrictions in the airway were more severe and the length of hospital stay was longer in the viral panel-positive group. Seemungal et al. reported that exacerbations associated with respiratory viruses had a longer median symptom recovery time than non-viral exacerbations (13 and 6 days, respectively) (7). Viral positivity has also been associated with a greater degree of systemic inflammation. The mean plasma fibrinogen level was two-times higher in the viral exacerbations than in the non-viral exacerbations (7). CRP levels indicating systemic inflammation were higher than normal in both the positive and negative viral panel groups, and no difference was identified between the two groups. Cals et al. demonstrated that plasma CRP level cannot predict the presence of a potentially pathogenic microorganism in the sputum (20).

The role and choice of antibiotics in the treatment of exacerbations remains as a matter of controversy, and not all patients are advised to start antibiotherapy $(21,22)$. Antibiotics are the mainstay treatment for 
patients with moderate to severe COPD with exacerbations that include increased purulence sputum (12). The criteria proposed by Anthonisen et al. seem to be the most useful means of estimating the probability of success with antibiotics, since their use seems to be beneficial in both type I and type II exacerbations of bacterial origin $(23,24)$. On the other hand, PCT has been accepted as a more sensitive marker of bacterial infection, and it has been suggested to assist in selection of patients that will benefit most from antibiotherapy $(25,26)$.

The CT signs of pulmonary viral infection depend on the underlying pathologic process and histopathologic features. These include diffuse alveolar damage (intraalveolar edema, fibrin, and variable cellular infiltrates with a hyaline membrane), intraalveolar hemorrhage and interstitial (intrapulmonary or airway) inflammatory cell infiltration (27). Radiological findings are often bilateral in viral pneumonia. Reticular and reticulonodular opacities, patchy alveolar infiltrates with ill-defined contours, peribronchial thickening, tree-in-bud and ground-glass appearance are observed that are more prominent in the perihilar region (27). Radiological findings suggesting viral pneumonia were more common in the viral panel-positive group.

There are a number of limitations to this study. First, the respiratory viruses which is detected from nasopharyngeal swabs by PCR technique is indistinguishable from colonization.

Secondly, all of the respondents in the study were inpatients. Patients presenting to outpatient clinics or those treated in the emergency departments could also have been included, as all COPD exacerbations would have been evaluated and the number of patients would be higher. Thirdly, another potential source of bias is the date of the study because of seasonality of respiratory viral infections.

In summary, this study supports the hypothesis that a significant proportion of hospitalized patients with exacerbations of COPD have respiratory viral infections. Rhinovirus was the most common viral infection detected, followed by influenza and coronavirus. Viral respiratory tract infections come to mind in first place if the procalcitonin level is low in a patient with radiological findings suggestive of viral pneumonia who is hospitalized with an exacerbation of COPD and who is suffering from severe airway restriction, frequent exacerbations and prolonged hospitalizations. The use of broad-spectrum antibiotics must be avoided in patients exhibiting such characteristics.

\section{CONFLICT of INTEREST}

All authors have no conflict of interests.

\section{AUTHORSHIP CONTRIBUTIONS}

Concept/Design: BY

Analysis/Interpretation: MS

Data Acquisition: DF

Writting: BY

Critical Revision: MS

Final Approval: BY

\section{REFERENCES}

1. Vestbo J, Hurd SS, Agustí AG, Jones PW, Vogelmeier C, Anzueto A, et al. Global strategy for the diagnosis, management, and prevention of chronic obstructive pulmonary disease: GOLD executive summary. Am / Respir Crit Care Med 2013;187:347-65.

2. Rodriguez-Roisin R. Toward a consensus definition for COPD exacerbations. Chest 2000;117:398S-401S.

3. Burge $S$, Wedzicha J. COPD exacerbations: definitions and classifications. Eur Respir I Suppl 2003;41:46s-53s.

4. Celli BR, MacNee W, Agusti A, Anzueto A, Berg B, Buist $A S$, et al. Standards for the diagnosis and treatment of patients with COPD: a summary of the ATS/ERS position paper. Eur Respir J 2004;23:932-46.

5. Papi A, Bellettato CM, Braccioni F, Romagnoli M, Casolari $P$, Caramori $G$, et al. Infections and airway inflammation in chronic obstructive pulmonary disease severe exacerbations. Am J Respir Crit Care Med 2006;173:1114-21.

6. Sethi S, Murphy TF. Bacterial infection in chronic obstructive pulmonary disease in 2000: a state-of-the-art review. Clinical microbiology reviews. Clin Microbiol Rev 2001;14:336-63.

7. Seemungal T, Harper-Owen R, Bhowmik A, Moric I, Sanderson G, Message $S$, et al. Respiratory viruses, symptoms, and inflammatory markers in acute exacerbations and stable chronic obstructive pulmonary disease. Am J Respir Crit Care Med 2001;164:1618-23.

8. Wedzicha JA. Role of viruses in exacerbations of chronic obstructive pulmonary disease. Proc Am Thorac Soc 2004; 1:115-20.

9. Ko FW, Ip M, Chan PK, Chan MC, To K-W, Ng SS, et al. Viral etiology of acute exacerbations of COPD in Hong Kong. Chest 2007;132:900-8. 
10. Gorse GI, O'Connor TZ, Young SL, Habib MP, Wittes I, Neuzil KM, et al. Impact of a winter respiratory virus season on patients with COPD and association with influenza vaccination. Chest 2006;130:1109-16.

11. Sapey E, Stockley RA. COPD exacerbations. 2: Aetiology. Thorax 2006; 61:250-8.

12. Sethi S. Bacterial infection and the pathogenesis of COPD. Chest 2000;117:286S-91S.

13. Smith CB, Golden CA, Kanner RE, Renzetti Jr AD. Association of viral and Mycoplasma pneumoniae infections with acute respiratory illness in patients with chronic obstructive pulmonary diseases. Am Rev Respir Dis 1980;121:225-32.

14. Mohan A, Chandra S, Agarwal D, Guleria R, Broor S, Gaur $B$, et al. Prevalence of viral infection detected by PCR and $R T-P C R$ in patients with acute exacerbation of COPD: a systematic review. Respirology 2010;15:536-42.

15. Camargo $C A$, Ginde $A A$, Clark S, Cartwright $C P$, Falsey $A R$, Niewoehner DE. Viral pathogens in acute exacerbations of chronic obstructive pulmonary disease. Intern Emerg Med 2008;3:355.

16. Rohde G, Wiethege A, Borg I, Kauth M, Bauer T, Gillissen $A$, et al. Respiratory viruses in exacerbations of chronic obstructive pulmonary disease requiring hospitalisation: a case-control study. Thorax 2003;58:37-42.

17. Dimopoulos G, Lerikou M, Tsiodras S, Chranioti A, Perros E, Anagnostopoulou $U$, et al. Viral epidemiology of acute exacerbations of chronic obstructive pulmonary disease. Pulm Pharmacol Ther 2012;25:12-8.

18. Beckham JD, Cadena A, Lin J, Piedra PA, Glezen WP, Greenberg $S B$, et al. Respiratory viral infections in patients with chronic, obstructive pulmonary disease. J Infect 2005; $50: 322-30$

19. Dai M-Y, Qiao J-P, Xu Y-h, Fei G-H. Respiratory infectious phenotypes in acute exacerbation of COPD: an aid to length of stay and COPD Assessment Test. Int I Chron Obstruct Pulmon Dis 2015;10:2257-63.
20. Cals IW, Butler CC, Hopstaken RM, Hood K, Dinant G-J. Effect of point of care testing for $C$ reactive protein and training in communication skills on antibiotic use in lower respiratory tract infections: cluster randomised trial. Bmj 2009;338:b1374.

21. Bach PB, Brown C, Gelfand SE, McCrory DC. Management of acute exacerbations of chronic obstructive pulmonary disease: a summary and appraisal of published evidence. Annals of Internal Medicine 2001;134:600-20.

22. Murphy TF, Sethi S, Niederman MS. The role of bacteria in exacerbations of COPD: a constructive view. Chest 2000;118:204-9.

23. Anthonisen N, Manfreda J, Warren C, Hershfield E. Antibiotic therapy in exacerbations of chronic obstructive pulmonary. Ann Intern Med 1987;106:196-204.

24. Ram FS, Rodriguez-Roisin R, Granados-Navarrete $A$, Garcia-Aymerich J, Barnes NC. Antibiotics for exacerbations of chronic obstructive pulmonary disease. Cochrane Database Syst Rev 2006:CD004403.

25. Simon L, Gauvin F, Amre DK, Saint-Louis P, Lacroix J. Serum procalcitonin and C-reactive protein levels as markers of bacterial infection: a systematic review and metaanalysis. Clin Infect Dis 2004;39:206-17.

26. Stolz D, Christ-Crain M, Bingisser R, Leuppi J, Miedinger D, Müller $C$, et al. Antibiotic treatment of exacerbations of COPD: a randomized, controlled trial comparing procalcitonin-guidance with standard therapy. Chest 2007;131:9-19.

27. Franquet T. Imaging of pulmonary viral pneumonia. Radiology 2011;260:18-39. 